\title{
Time Series Changes in Fish Assemblages and Habitat Structures Caused by Partial Check Dam Removal
}

\author{
Shigeya Nagayama ${ }^{1,2, *}$, Nobuo Ishiyama ${ }^{1,3}$, Taro Seno ${ }^{1,4}$, Hideyuki Kawai ${ }^{1,5}$, \\ Yoichi Kawaguchi ${ }^{1,6}$, Daisuke Nakano ${ }^{1,7}$ and Futoshi Nakamura ${ }^{1}$ \\ 1 Graduate School of Agriculture, Hokkaido University, Kita 9 Nishi 9, Kita-ku, Sapporo, \\ Hokkaido 060-8589, Japan; night7mare@gmail.com (N.I.); taro.seno@greenpower.co.jp (T.S.); \\ hkawai@mmc.co.jp (H.K.); kawaguchi@ce.tokushima-u.ac.jp (Y.K.); d-nakano@criepi.denken.or.jp (D.N.); \\ nakaf@for.agr.hokudai.ac.jp (F.N.) \\ 2 Regional Adaptation Research Center, Gifu University, 1-1, Yanagido, Gifu, Gifu 501-1193, Japan \\ 3 Hokkaido Research Organization, Forest Research Institute, Kosyunai, Bibai, Hokkaido 079-0198, Japan \\ 4 Green Power Investment Corporation, Akasaka Intercity 3F, 1-11-44, Akasaka, Minato-ku, \\ Tokyo 105-0052, Japan \\ 5 Mitsubishi Materials Corporation, 3-2-3, Marunouchi, Chiyoda-ku, Tokyo 100-8117, Japan \\ 6 Graduate School of Technology, Industrial and Social Sciences, Tokushima University, 2-1 Minami-Josanjima, \\ Tokushima 770-0814, Japan \\ 7 River and Coastal Environment Sector, Environmental Science Laboratory, Central Research Institute of \\ Electric Power Industry (CRIEPI), 1646 Abiko, Abiko, Chiba 270-1194, Japan \\ * Correspondence: nagayama@gifu-u.ac.jp; Tel.: +81-58-293-2474
}

Received: 11 September 2020; Accepted: 27 November 2020; Published: 30 November 2020

\begin{abstract}
Despite a steep increase in dam removal projects, there are few studies on the biophysical responses to dam removal. In this study, we evaluated the short-term (1.5 years) and long-term (5.5 years) effects of partial check dam removal on fish assemblages and their habitats. First, the habitat preferences of fish were examined at a channel unit scale: pools, rapids, and side channels satisfied the seasonal habitat requirements of the fish assemblages. Partial check dam removal increased the abundance of these habitats and diversified the habitat structures owing to the sediment release from the dam; in contrast, the bedrock distinctly decreased 1.5 years after dam removal. However, 5.5 years after dam removal, the bedrock proportion increased, and the habitat structures were simplified again owing to the re-transportation of sediments. Similar temporal changes were also determined through a reach-scale analysis with a change in the bed materials. Anadromous Oncorhynchus masou began to spawn and recolonize in the upstream section of the dam after the dam removal, causing similar assemblage compositions between the downstream and upstream sections. The abundance of Salvelinus malma and Noemacheilus barbatulus toni in the upstream reaches decreased over time after the dam removal. The temporal changes in the biophysical responses suggest that long-term monitoring is indispensable for the reliable evaluation of dam removal effects.
\end{abstract}

Keywords: bedrock outcrop; ecological trade-off; habitat preference; long-term monitoring; sediment transportation

\section{Introduction}

A steep increase in dam removal projects has been observed owing to increasing economic, safety, and environmental concerns. There have been more than 3450 dam removal projects in Europe [1], 1300 in the United States [2], and 394 in Japan [3]. The number of dam removal projects rapidly increased starting in the 1990s and continues to increase [4,5]. Dams are considered to cause wide-ranging effects on river ecosystems because of the alterations of flow and sediment regimes, disruption of the 
channel network, habitat alteration, and limitations of the accessible area for aquatic organisms $[4,6,7]$. Thus, dam removal is considered to be a significant step for river restoration.

Owing to the increase in dam removal projects, several studies on the effects on the river ecosystem are being conducted [8]. However, only $9 \%$ of dam removals in the United States were scientifically evaluated, and most of these studies focused on the hydrologic and geomorphic responses, with short evaluation ( $<4$ years) and limited (1-2 years) or no pre-removal monitoring [8]. Studies on the geomorphic responses of the Kuma River to the first Japanese high-dam removal (the Arase dam removal project) recently began $[9,10]$. In Europe, there have been fewer studies on dam removal compared to the number of dam removal projects [1]. Thus, there are fewer studies on predicting the biophysical responses to dam removal [11-13] compared to those on hydrologic and geomorphic responses.

There is a lack of long-term assessments of the biophysical responses before and after dam removal on a global scale [2,8]. Geomorphic and ecological responses to dam removal can move toward a new equilibrium condition over time as reservoir sediments stabilize and/or new sediment regimes are established [14]. Thus, studies based on short-term monitoring may neglect or misunderstand some of the biophysical responses to dam removal. For example, an early effect of dam removal was the deterioration of salmonid spawning habitats caused by fine sediment accumulation in the downstream reaches of the dam [15]. Other early drastic habitat changes that can potentially damage aquatic organisms have been reported following dam removal; massive sediment deposition (riverbed aggradation), active channel widening, and changes in the channel form [16-19]. Alternatively, dam removal could eventually help improve the river ecosystem through recovery of the natural sediment regime. The coarsening of riverbed materials (armor coat) and bedrock outcrop are the primary causes of ecological issues in the downstream reaches of dams. For example, these riverbed conditions can decrease the fish abundance and cause deterioration of salmonid spawning habitats $[6,20]$. These issues can be mitigated by recovering the sediment supply after dam removal. Long-term monitoring can evaluate the biophysical responses, including the ecological trade-off on a temporal scale.

In the Ikeshomanai Stream, there were ecological problems associated with a check dam, including habitat homogenization with a bedrock outcrop in the downstream reaches of the dam and a limitation to the upstream spawning migration of anadromous Oncorhynchus masou (masu salmon). In 2009, the check dam was partially removed to solve these problems. The purpose of this study is to evaluate the short-term (1.5 years) and long-term (5.5 years) effects of partial dam removal on fish habitats and assemblages. First, at the channel unit scale, we examined the habitat preferences of all species of fish at our study site based on seasons and body sizes. Subsequently, time series changes in the distribution and composition of habitats (channel units) were examined in the downstream section of the dam before and after the dam removal. Second, time series changes in the physical environments and fish assemblages at the reach scale were evaluated for the downstream and upstream reaches, before and after the dam removal. Third, the distribution of the redds of anadromous masu salmon was investigated before and after the dam removal.

\section{Materials and Methods}

\subsection{Study Streams and Partial Dam Removal}

This study was conducted in two small mountain streams-the Ikeshomanai and Toubatsu Streams, which are on opposite sides of the mainstem of the Churui River, in eastern Hokkaido, Japan (Figure 1). The watersheds of both these streams were entirely covered with forests and volcanic rock consisting of green tuff with sandstone and shale. The watershed areas were 15.0 and $22.4 \mathrm{~km}^{2}$, and the wetted channel widths were approximately 6.0 and $10.0 \mathrm{~m}$ in the Ikeshomanai and Toubatsu Streams, respectively. The riverbed gradient of the lower sections of both streams, including the study sites, was $1.0-2.0 \%$. The channel type of these streams was identified as "plane-bed" and 
"pool-riffle" [21]. There were no artificial constructions on the Toubatsu Stream, whereas a check dam was constructed on the Ikeshomanai Stream (48 m wide and $4 \mathrm{~m}$ high), and it was located $1 \mathrm{~km}$ upstream from the confluence of the Churui River (Figure 1). This check dam was constructed in 1969 to conserve the forests on mountain slopes by preventing riverbed degradation and landslides.

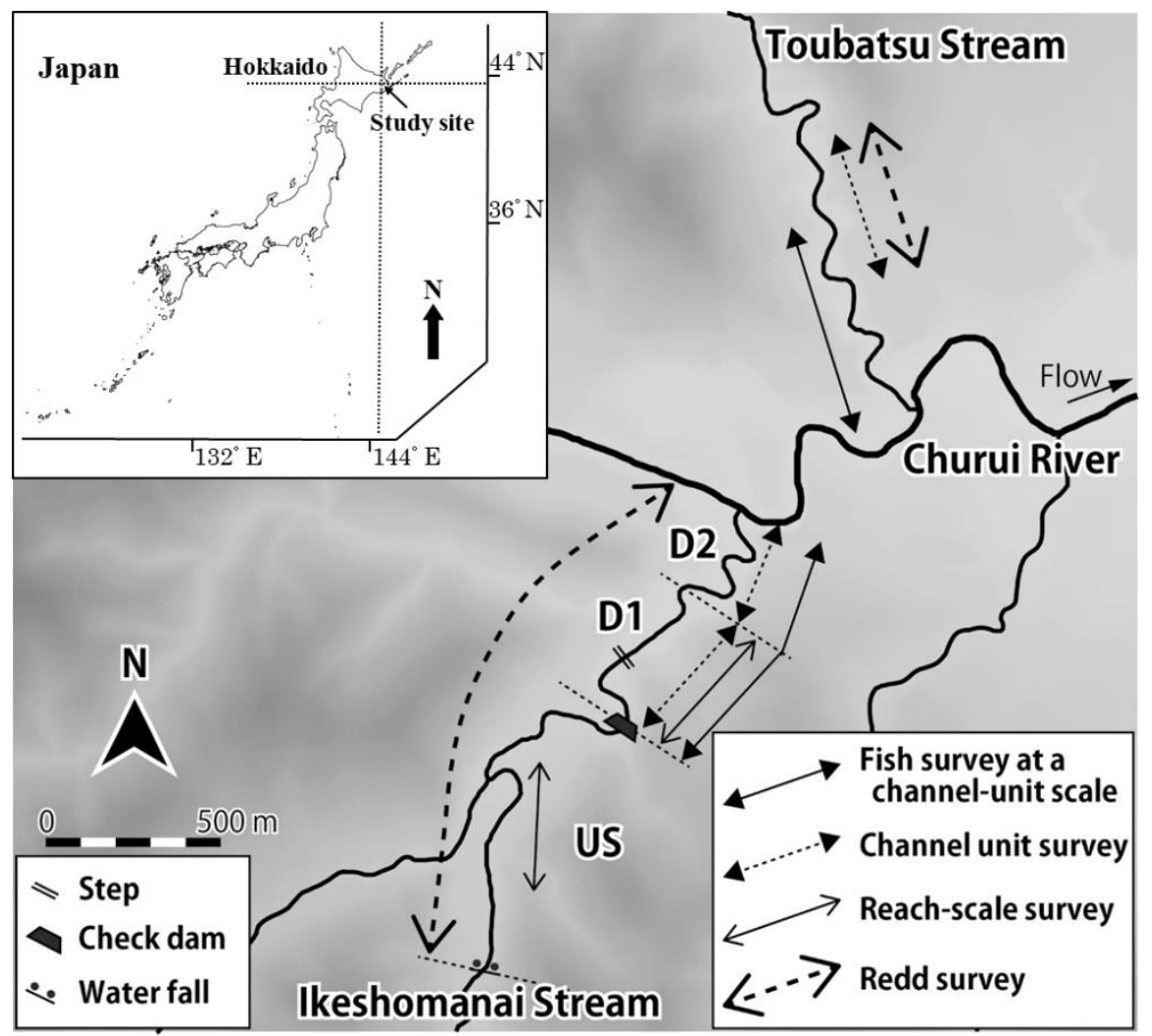

Figure 1. The location of the study streams and allocation of the study sections for the different surveys.

However, the check dam caused two visible ecological problems: prevention of the upstream migration of fish and downstream habitat homogenization with a bedrock outcrop due to the limited sediment supply. In our study region, almost all females of masu salmon migrate to the ocean after one year of living in the stream [22]. When these adult females returned from the ocean and could not migrate beyond the dam, the masu salmon population disappeared above the dam. Thus, before dam removal in the Ikeshomanai Stream, masu salmon were absent in the upstream section of the check dam.

The check dam in the Ikeshomanai Stream was partially, but extensively, removed in the shape of an inverse trapezoid in February 2009 (Figure 2). Before the removal, the check dam was filled with sediment. The dam was opened at a portion slightly toward the left of the center of the dam to maintain the stability of the upstream right bank (mountain slope). The bottom of the removed part of the dam was $4 \mathrm{~m}$ wide and had the same elevation as the downstream riverbed. Thus, the partial dam removal enabled the upstream migration of fish for the first time in four decades and led to dynamic geomorphic changes in the upstream and downstream sections of the dam. In addition, impounded sediments were eroded after the dam removal in a process similar to the one reported by Collins et al. [23] (Figure A1); the erosion ultimately reached more than $300 \mathrm{~m}$ upstream. The eroded sediments removed from the dam changed the morphology of the downstream channel; for example, a natural small step ( $>1.5 \mathrm{~m}$ high) located $250 \mathrm{~m}$ downstream from the dam was completely buried following dam removal, although it subsequently reappeared (Figures 1 and A2). 


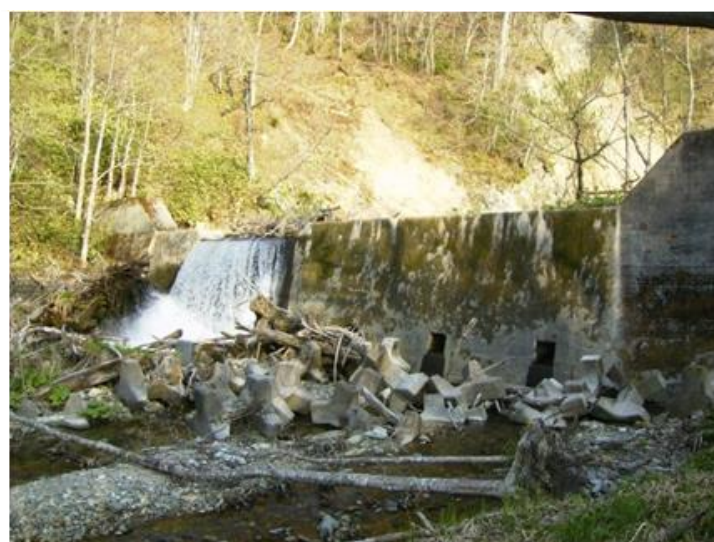

(a)

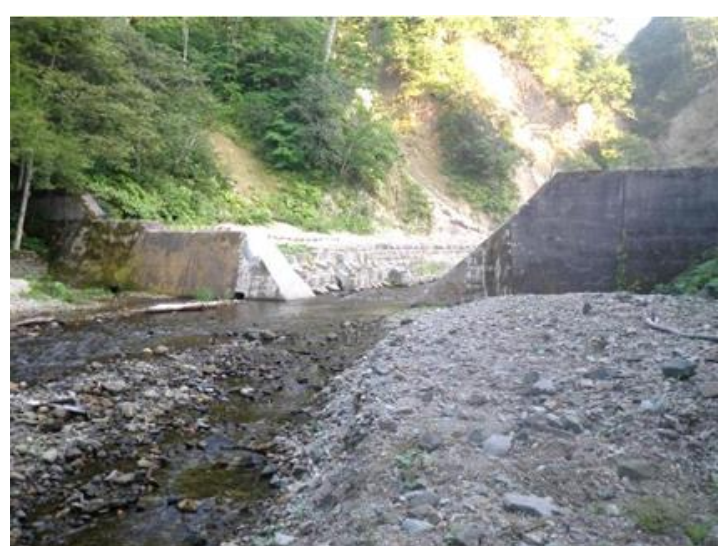

(b)

Figure 2. The check dam before (a) and after (b) the partial dam removal implemented in February 2009.

The flow discharge was not continuously observed in the study streams. As a reference for the fluctuation in the flow discharge, we used the daily precipitation reported at the nearest precipitation station (Itokushibetsu station), located $4.6 \mathrm{~km}$ east of the study streams (Figure 3). Based on measurements on transects in the reach-scale survey (also see below), the discharge at base flow conditions was $0.58-0.97 \mathrm{~m}^{3} / \mathrm{s}$. The peak discharge of flooding on 23 June 2009 was approximately estimated at $>48.5 \mathrm{~m}^{3} / \mathrm{s}$ based on the precipitation and flood evidence.

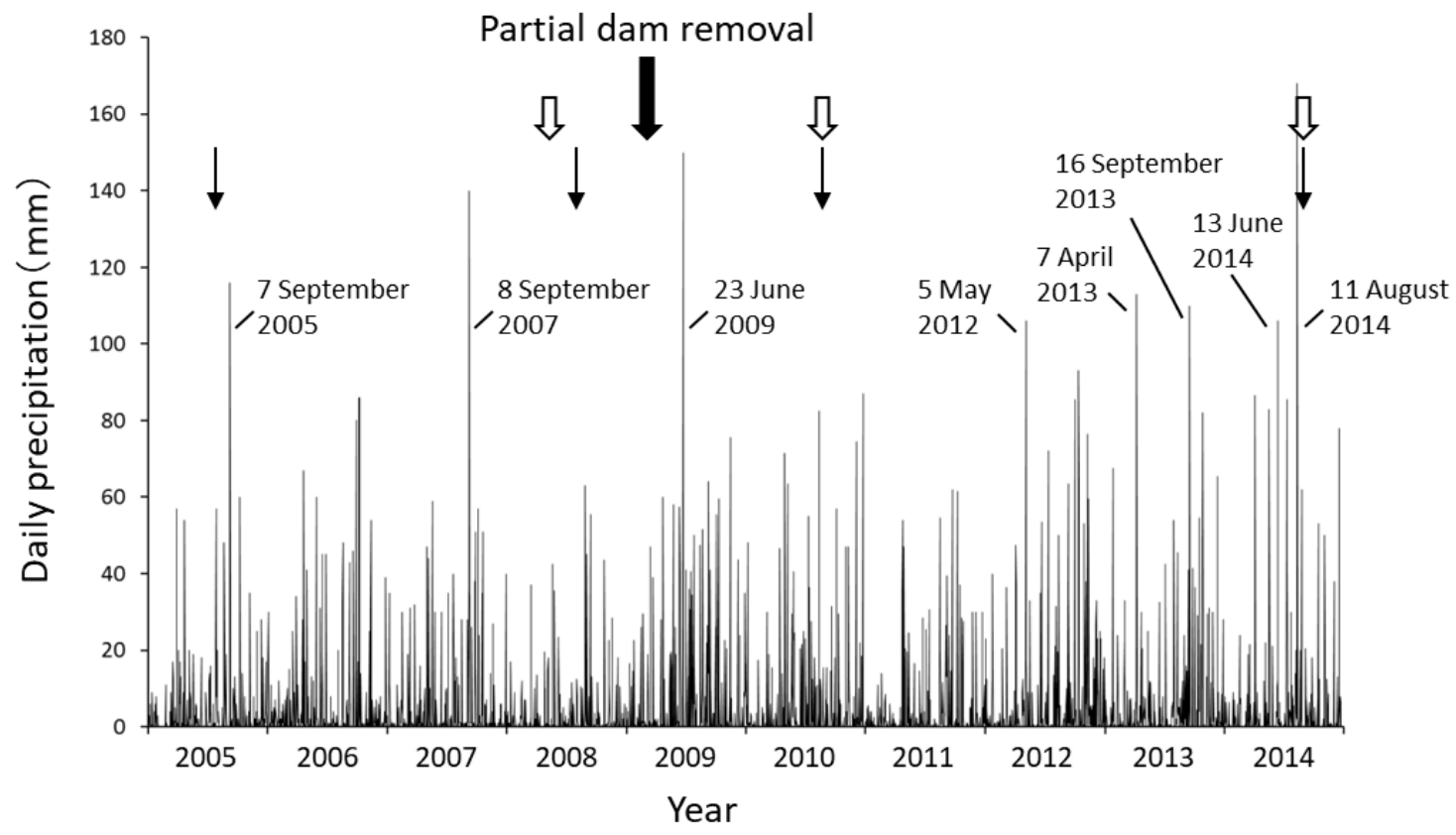

Figure 3. Daily precipitation observed at the Itokushibetsu station from 1 January 2005 to 31 December 2014. The solid arrow denotes when the dam was partially removed (February 2009). The open arrows denote the surveys for channel unit structures. The thin arrows indicate the reach-scale surveys for fish assemblages and physical environments. Dates with high precipitation (over $100 \mathrm{~mm} /$ day) are also shown. 


\subsection{Study Design}

The effect of dam removal on the fish habitats in the downstream section of the dam was evaluated based on the following two assessments. First, the seasonal habitat preferences of all fish species in the study streams were assessed at the channel-unit scale (a spatial scale with $c .10^{0}$ channel widths). From this assessment, we investigated the critical and noncritical habitats for fish assemblages in our study streams. Second, spatiotemporal changes in the channel unit structure in the Ikeshomanai Stream were assessed before (2008) and after dam removal (2010 and 2014). In 2008, the channel unit structure was also assessed for the Toubatsu Stream, wherein no check dams were constructed. We considered this as a habitat reference for the study.

To evaluate the biophysical responses to dam removal, temporal changes in the physical environments and fish assemblages were assessed in the downstream and upstream reaches of the dam in the Ikeshomanai Stream before (2005 and 2008) and after dam removal (2010 and 2014). This assessment was performed at the reach scale (a spatial scale with $c .10^{1}$ channel widths). Prior to dam removal, the physical environments and fish assemblages were different between the downstream and upstream reaches: there were distinct bedrock outcrops in the downstream reaches and an absence of masu salmon in the upstream reaches. We predicted that dam removal would recover the sediment transportation and fish migration between the downstream and upstream sections of the dam; thus, we examined whether the physical environments and fish assemblages increased in similarity between the downstream and upstream reaches following dam removal. This examination allows us to understand the biophysical responses to dam removal without concerns regarding the annual variability of fish populations and environmental conditions as those factors should equivalently affect both the downstream and upstream reaches. No control sites with similar hydrogeomorphic characteristics to Ikeshomanai Stream were found in neighboring tributaries. Here, the Toubatsu Stream was not regarded as a control site due to differences in the catchment area and channel width. Instead, we focused on Ikeshomanai Stream for a time series analysis of the biophysical responses associated with dam removal.

To verify the recovery of the upstream migration of spawning masu salmon, the distribution of masu salmon redds was investigated in the Ikeshomanai Stream before (2008) and after (2010) dam removal and in the Toubatsu Stream in 2008.

\subsection{Fish Survey at a Channel Unit Scale}

Based on our preliminary survey and existing classification system of the channel units [24], five habitat types were identified in the study streams: pools, rapids, bedrock, riffles, and side channels. A pool was a deep channel unit with a slow current velocity $(45.2 \mathrm{~cm}$ in mean depth and $28.6 \mathrm{~cm} / \mathrm{sec}$ in mean current velocity); a rapid was a steep channel unit with swift and turbulent flows $(24.2 \mathrm{~cm}$ and $69.3 \mathrm{~cm} / \mathrm{s})$; a bedrock was a channel unit that outcropped broadly $(19.7 \mathrm{~cm}$ and $54.4 \mathrm{~cm} / \mathrm{s})$; a riffle was a channel unit with swift and shallow waters $(20.4 \mathrm{~cm}$ and $38.9 \mathrm{~cm} / \mathrm{s})$ with a lower gradient $(<3 \%$ in general) than that of the rapid; a side channel was a small channel $(10.1 \mathrm{~cm}, 4.4 \mathrm{~cm} / \mathrm{s}$, and $1.9 \mathrm{~m}$ in mean width) connected to the main channel at its uppermost and/or lowermost ends and was generally formed in association with gravel bars.

The fish sampling was performed using a backpack electrofishing unit (Model 12, Smith-Root Inc., Vancouver, WA, USA) during 7-11 June (spring, water temperature $=8.7-14.5^{\circ} \mathrm{C}$ ), $11-14$ August (summer, $13.1-17.4{ }^{\circ} \mathrm{C}$ ), and $25-28$ November (winter, $0-2.3^{\circ} \mathrm{C}$ ), 2008. A total of $10-14$ channel units were collected for each habitat type during each sampling season. The sampling units were set in a $1.1-\mathrm{km}$ section from the confluence of the Churui River in each of the study streams (Figure 1). In the Ikeshomanai Stream, the section for the fish survey nearly corresponded to the entire downstream section of the check dam. The electrofishing survey was conducted by a three-person crew: two people used dip nets and large D-shaped nets (1.0 m width, $0.8 \mathrm{~m}$ height, and $1.1 \mathrm{~m}$ depth), and the third used an electrofishing unit and a dip net. The number of fish in each sampling unit was estimated by single-pass electrofishing, and this was used to calculate the fish abundance $\left(\mathrm{N} / \mathrm{m}^{2}\right)$ in each of 
the habitats. After sampling the fish, three widths and a midline length of each sampling unit were measured to calculate the area. The widths were measured on three equally spaced transects perpendicular to the stream flow.

Three fish species were observed: masu salmon, Salvelinus malma (Dolly Varden), and Noemacheilus barbatulus toni (Siberian stone loach). Small individuals of salmonids prefer habitats with a slow current velocity, and the habitat use shifts when they grow older $[25,26]$. Therefore, we classified masu salmon and Dolly Varden based on the size distributions, obtained our data and counted the number of individuals. The size classes were, MS-S: small-sized ( $\leq 60 \mathrm{~mm}$ in folk length) masu salmon, MS-L: large-sized ( $>60 \mathrm{~mm}$ in folk length) masu salmon, DV-S: small-sized ( $\leq 65 \mathrm{~mm}$ in folk length) Dolly Varden, and DV-L: large-sized ( $>65 \mathrm{~mm}$ in folk length) Dolly Varden. The number of Siberian stone loach (SL) was counted without size classification because there was no information regarding habitat use for different size classes.

Most MS-S and DV-S are the young-of-the-year (YOY) because these species emerge from the spawning bed during early spring and commonly grow to $>65 \mathrm{~mm}$ until the winter of the year [27]. Most MS-L and DV-L observed in the spring are one year old and older, whereas in summer and winter, the grown YOY are also included in these classes.

\subsection{Survey of Channel Unit Structures}

The distribution and composition of channel units were investigated in the Ikeshomanai Stream through the pre- (2008) and post-dam-removal (2010 and 2014) periods, and in the Toubatsu Stream in 2008 (Figures 1 and 3). On 17 May 2008, the survey was conducted in a 500-m section (D1) immediately downstream from the dam in the Ikeshomanai Stream and in a 600-m section in the Toubatsu Stream. On 30 August 2010 and 3 September 2014, an entire downstream section (D1 and D2) of the dam was investigated in the Ikeshomanai Stream. D2 was a downstream section of D1 and connected with the Churui River.

The distribution of the channel units was detected using the differential global positioning system (DGPS). The investigator with the DGPS walked along the midchannel of the stream and side channels and obtained the line data. The investigator determined the habitat type and stored this information with the line data; therefore, the line data consisted of habitat types. The lengths of each habitat were measured in ArcMap (ArcEditor ver. 10.0; Esri Co., Redlands, CA, USA) and were used to determine the composition of habitat types.

\subsection{Survey of Biophysical Responses at a Reach Scale}

The physical environments and fish assemblages were investigated in six reaches (each $50 \mathrm{~m}$ long) set in each of the downstream and upstream sections of the dam in the Ikeshomanai Stream before (2005 and 2008) and after (2010 and 2014) dam removal (Figures 1 and 3). These surveys were conducted in late July to late August in each study year. The downstream reaches were allocated at $c$. $40 \mathrm{~m}$ intervals in a $500 \mathrm{~m}$ section (D1) downstream from the dam. The upstream reaches were allocated at c. $40 \mathrm{~m}$ intervals in a $500 \mathrm{~m}$ section (US), $500 \mathrm{~m}$ away from the dam, where the dam had not directly affected the geomorphic features.

An electrofishing survey for each study reach was performed in the above-mentioned method, and the number of individuals of each of three fish species was counted without size classification and was used to calculate the fish abundance $\left(\mathrm{N} / \mathrm{m}^{2}\right)$. After sampling the fish, the physical environments (current velocity, depth, substrate size, and channel width) were measured in each study reach. Twenty transects perpendicular to the stream flow were established at 2.5-m intervals in each study reach. Each transect had five measurement points at the same intervals (100 measurement points in total in each study reach). These transects were numbered upward in an ascending order (transect number 1-20). The current velocity and depth were measured at measurement points on odd-numbered transects (50 measurements in total). The current velocity was measured at a $60 \%$ depth with a portable current meter (Flow-MATE Model 2000; Marsh-McBirney Inc., Frederick, MD, USA). The substrate 
size was measured at measurement points on all transects (100 measurements in total) and was used to calculate the proportion of substrate types: bedrock, sand $(<2 \mathrm{~mm})$, gravel $(2-16 \mathrm{~mm})$, pebble ( $>16-64 \mathrm{~mm})$, cobble $(>64-256 \mathrm{~mm})$, and boulder $(>256 \mathrm{~mm})$. The wetted channel width was also measured at all transects and used to calculate the area of the study reach and fish abundance $\left(\mathrm{N} / \mathrm{m}^{2}\right)$.

\subsection{Survey of Masu Salmon Redd Distribution}

The distribution of masu salmon redds was investigated in the Ikeshomanai Stream before (2008) and after (2010) dam removal, and in the Toubatsu Stream in 2008 (Figure 1). A redd was easily identified as a set of a mound and a pit $>100 \mathrm{~cm}$ in length in total, which was constructed by spawning behavior. These surveys were conducted in late September in each year. In 2008, the redds were searched in the same sections as those in the survey for the channel unit structure in both streams. In 2010, the survey section in the Ikeshomanai Stream was extended to a $2.4-\mathrm{km}$ section from the confluence to the Churui River. In the uppermost part of the section, there was a natural fall preventing the upstream migration of spawning masu salmon. The investigator walked along the survey sections and recorded the locations of the masu salmon redds using DGPS.

\subsection{Data Analyses}

To estimate the relative preferences for the five habitat types by each fish group (MS-S, MS-L, DV-S, DV-L, and SL) in each season (spring, summer, and winter), Manly's $\alpha$, also known as Chesson's selectivity index [28,29], was used.

$$
\alpha_{i}=\frac{r_{i} / n_{i}}{\sum_{i=1}^{m} r_{i} / n_{i}}, \quad i=1,2, \ldots, m
$$

where $\alpha_{i}$ is the preference value for an $i$-th habitat type (of $m$ types), $r_{i}$ is the mean fish abundance $\left(\mathrm{N} / \mathrm{m}^{2}\right)$ in the $i$-th habitat type, and $n_{i}$ is the proportion of the $i$-th habitat type in all sampling units. The proportions of the habitat types were calculated based on the channel unit lengths. The value of $\alpha_{i}$ ranges from 0 to 1 . In general, a value of $\alpha_{i}>1 / m$ (here, $1 / 5=0.2$ ) indicates a relative preference and a value of $\alpha_{i}<1 / m$ indicates a relative avoidance.

Principal component analysis (PCA) was performed using nine environmental variables (channel width, current velocity, depth, and the proportions of each of the six substrate types) to examine the temporal changes in the physical environments in the downstream and upstream reaches of the dam through the pre- (2005 and 2008) and post-dam-removal (2010 and 2014) periods. Forty-eight samples (12 reaches $\times 4$ years) were used for PCA. Prior to performing PCA, all environmental variables were standardized to have a mean of 0 and a standard deviation of 1.

Nonmetric multidimensional scaling (NMS) was conducted using the fish abundance (masu salmon, Dolly Varden, and Siberian stone loach) to examine the temporal changes in the composition of fish assemblages in the downstream and upstream reaches of the dam pre- (2005 and 2008) and post-dam-removal (2010 and 2014). NMS is a nonparametric ordination technique and is one of the most robust methods used for exploring biological community data [30]. NMS was performed using $R$ (ver. 3.6.1) [31] and the vegan package (metaMDS function) [32]. We used the Bray-Curtis distance measure. A total of 48 samples (12 reaches $\times 4$ years) were used in the analysis. 
The Wilcoxon rank sum test was performed to detect the differences in fish abundance (masu salmon, Dolly Varden, and Siberian stone loach) between the downstream and upstream reaches of the dam in each survey year $(2005,2008,2010$, and 2014) with a significance level of 0.05 .

\section{Results}

\subsection{Habitat Preference of Fish at a Channel Unit Scale}

The MS-S consistently showed a strong preference for the side channel throughout all seasons and a moderate preference for the pools in summer and winter (Figure 4). The MS-L showed a strong preference for the pools throughout all seasons and moderate preference to the rapids in summer and for the side channels in winter. The DV-S consistently preferred the side channels throughout all seasons, with distinct preferences in spring, and they preferred the pools only in winter. Throughout all seasons, the DV-L showed a preference for the pools and the rapids. The SL shifted their habitat preference seasonally: a moderate preference for the rapids and the side channels in spring and a strong preference for the rapids in summer and for the pools in winter. Although bedrock and riffle were used by a few fish of masu salmon and Dolly Varden in summer, no distinct preferences were observed. The Siberian stone loach also did not prefer the bedrock and the riffle throughout all seasons.

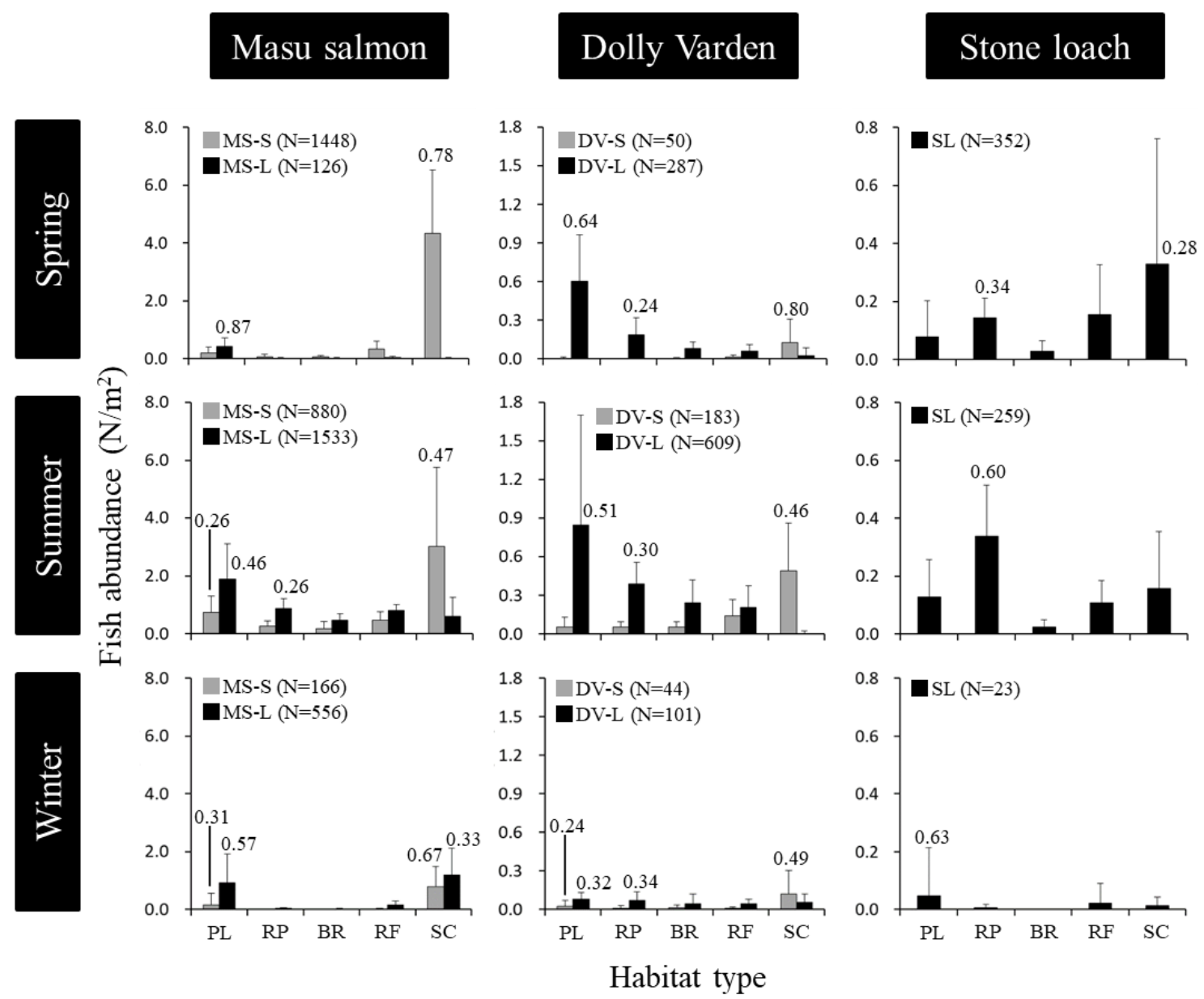

Figure 4. Seasonal changes in the fish abundance $\left(\mathrm{N} / \mathrm{m}^{2}\right)$ in each habitat type based on the 2008 survey. MS-S: small-sized ( $\leq 60 \mathrm{~mm}$ ) masu salmon, MS-L: large-sized ( $>60 \mathrm{~mm}$ ) masu salmon, DV-S: small-sized ( $\leq 65 \mathrm{~mm}$ ) Dolly Varden, DV-L: large-sized ( $>65 \mathrm{~mm}$ ) Dolly Varden, SL: Siberian stone loach. PL: pool, RP: rapid, BR: bedrock, RF: riffle, and SC: side channel. Error bars denote the standard deviation. Numbers above the bars denote Manly's $\alpha$ (selectivity index) $>0.2$, indicating a relative preference. 


\subsection{Spatiotemporal Changes in Channel Unit Structures}

In the Ikeshomanai Stream, the bedrock occupied $48.2 \%$ of D1 in 2008 before dam removal, whereas in the Toubatsu Stream, the bedrock occupied only $4.1 \%$ of the study section (Figure 5). In the Toubatsu Stream, the side channel occupied a large proportion (44.4\%) and other habitats (riffle, pool, and rapid) showed balanced composition with longitudinally repeated structures.

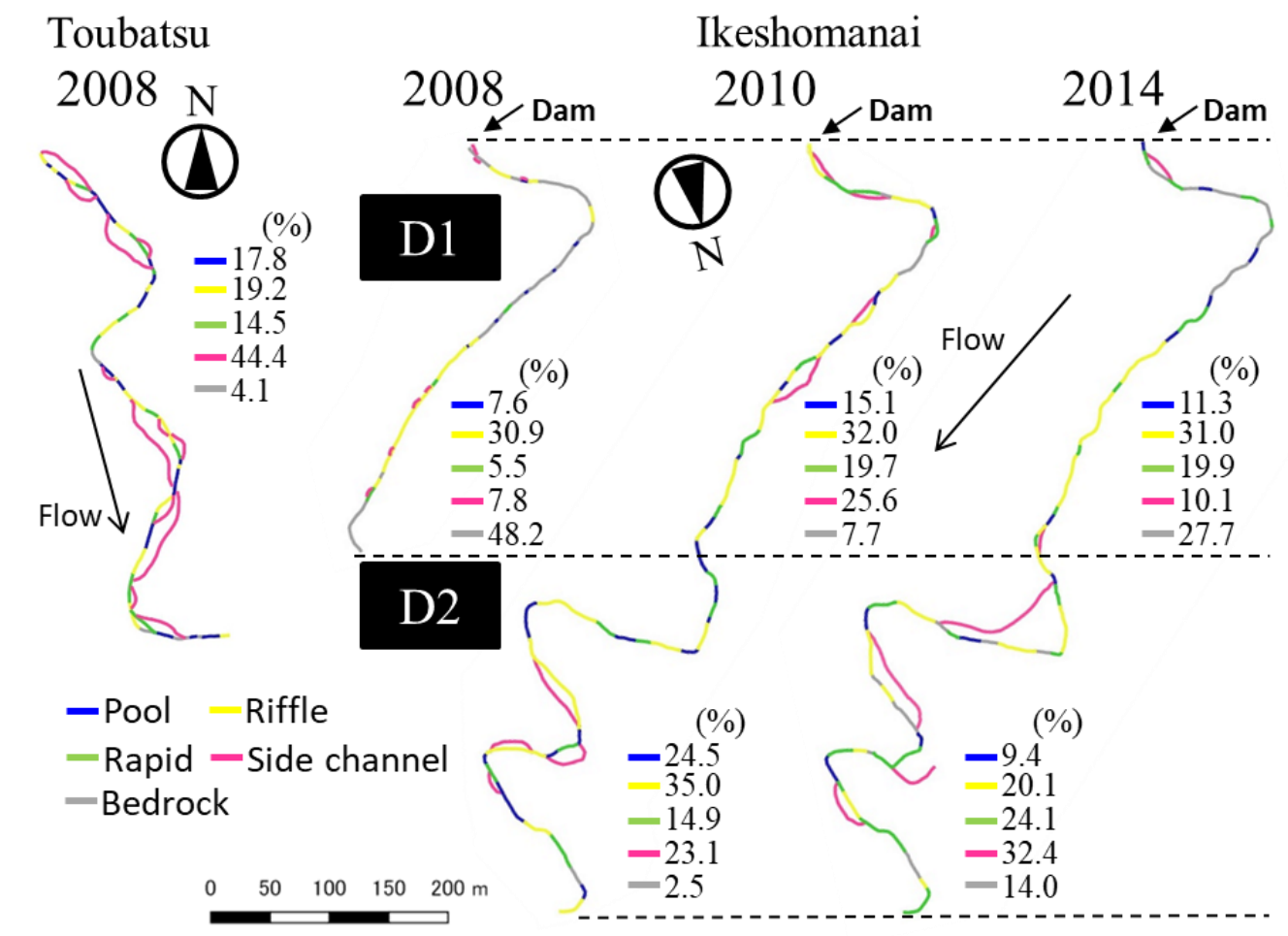

Figure 5. Spatiotemporal changes in the habitat distribution in the downstream section (D1 and D2) of the dam in the Ikeshomanai Stream before (2008) and after (2010 and 2014) dam removal (February 2009). The habitat distribution in the Toubatsu Stream, 2008 is also shown as reference. The numeric characters denote the percentage of habitat types in each study section in each year.

In 2010 (1.5 years after dam removal), the proportion of bedrock in D1 dramatically decreased (7.7\%, Figure 5). Instead, the proportion of side channels, pools, and rapids increased, and those repeated sequence structures were recovered to a state similar to that of the Toubatsu Stream. A small step, presented in D1, was mostly buried with sediments (Figure A2). Similar habitat structures were also found in D2.

In 2014 (5.5 years after dam removal), in D1, the bedrock increased again, and the side channel decreased by a similar proportion before the dam removal (2008) (Figure 5). In addition, the habitat structures were apparently simplified in D1, with long riffle and bedrock (Figure 5). Then, a small step, which was buried in 2010, appeared again (Figure A2). In contrast, the side channel increased in D2, although the bedrock also increased in comparison with 2010. 


\subsection{Temporal Changes in Physical Environments and Fish Assemblages at a Reach Scale}

The first axis (PC 1) explained 31.0\%, and the second axis (PC 2) explained 19.9\% of the variance (Figure 6). PC 1 was positively correlated with the proportion of cobble, and PC 2 was negatively correlated with the proportion of bedrock (Figure 6). From 2005 to 2008, before the dam removal, physical environments in both the downstream and upstream reaches of the dam changed similarly, with a decrease in pebble and slight increases in cobble and bedrock (Table 1, Figure 6). However, these plots in the diagram of PCA ordination were away from each other, and the bedrock was distinctly higher in the downstream reach; this indicated that the physical characteristics were clearly different between the downstream and upstream reaches (Table 1, Figure 6). In 2010 (1.5 years after dam removal), the downstream reach had a lower proportion of bedrock and a higher proportion of cobble (Table 1), and the plot was placed closer to that of the upstream reach (Figure 6). In 2014, (5.5 years after dam removal), the proportion of bedrock increased slightly in the upstream reach (Table 1), and the plot moved down in the diagram (Figure 6). Then, the plot of the downstream reach moved away from that of the upstream reach (Figure 6), with a decrease in cobble (Table 1).

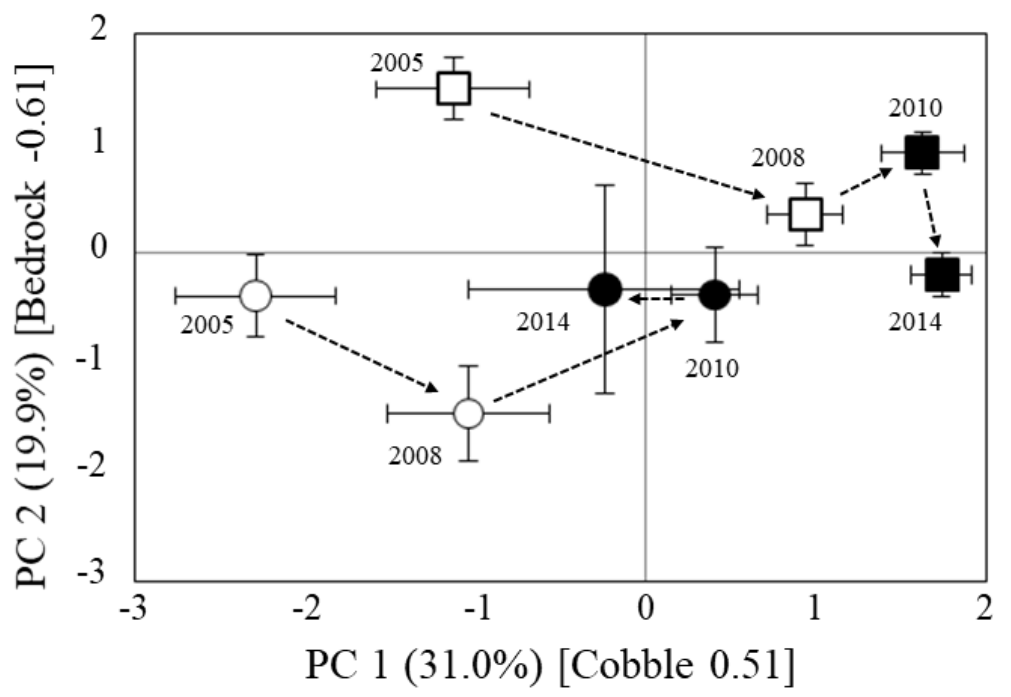

Figure 6. The principal component analysis (PCA) ordination of physical environments showing the temporal changes in the downstream (circle) and upstream reaches (square) of the dam. Open and solid plots indicate before and after the dam removal, respectively, and they express the means with \pm 1 standard errors for each axis. Numeric characters denote the survey years. The percent of variances and factor loadings $(>0.5$ and $<-0.5)$ of influential variables for each principal component $(\mathrm{PC})$ are also shown.

A two-axis solution produced a satisfactory NMS ordination (final stress $=0.09$ ) of the compositions of fish assemblages at our study reaches, with clear differentiation in the fish assemblage along the gradient of axis 1 values (Figure 7). From 2005 to 2008, before the dam removal, fish assemblages in both the downstream and upstream reaches changed similarly (Figure 7) with increases in the abundance of masu salmon and/or Dolly Varden (Figure 8). However, because masu salmon was absent in the upstream reaches before dam removal (Figure 8), the fish assemblages were distinctly different between the downstream and upstream reaches (Figure 7). In 2010 (1.5 years after dam removal), although the fish assemblage in the downstream reach did not change, that in the upstream reach changed dramatically and was closer to that in the downstream reach (Figure 7), owing to the appearance of masu salmon in the upstream reach (Figure 8). From 2010 to 2014, the fish assemblages in both reaches changed (Figure 7): masu salmon and Dolly Varden decreased in the downstream reach, and Dolly Varden and Siberian stone loach decreased in the upstream reach (Figure 8). The abundance of masu salmon and Siberian stone loach were not statistically different between the downstream 
and upstream reaches in 2014; however, the abundance of Dolly Varden continued to be higher in the upstream reach compared with in the downstream reach throughout the study years (Figure 8).

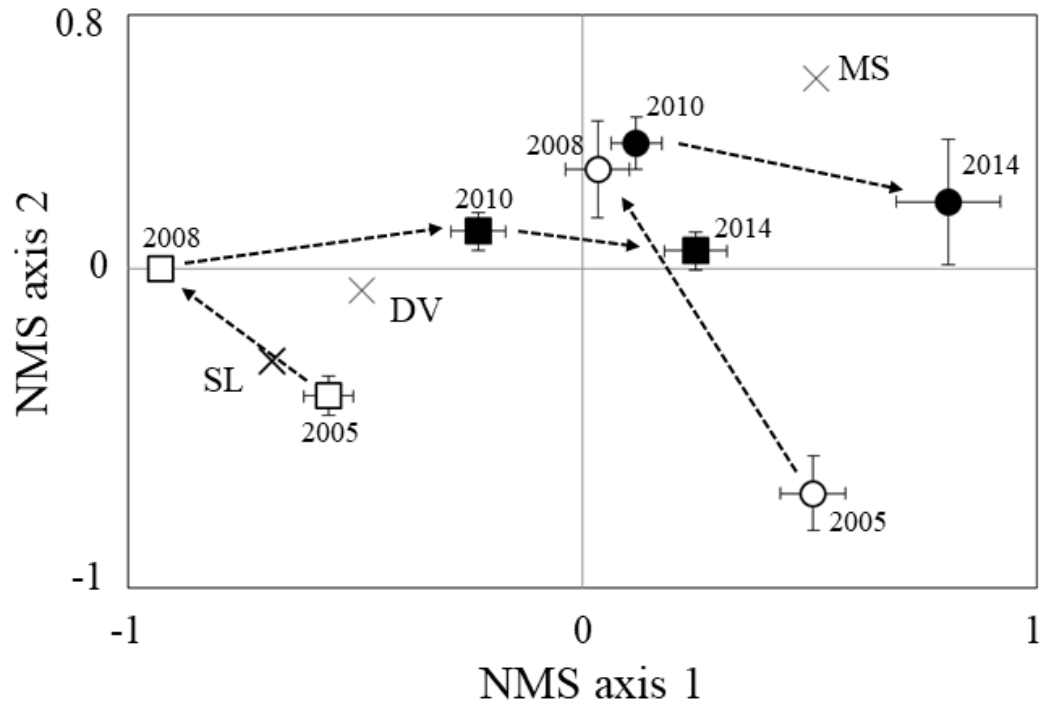

Figure 7. Nonmetric multidimensional scaling (NMS) ordination of fish assemblages showing the temporal changes in the downstream (circle) and upstream reaches (square) of the dam. Open and solid plots indicate before and after the dam removal, respectively, and they express the means with \pm 1 standard errors for each axis. Numeric characters denote the survey years. Species are denoted by cross-marks with abbreviations: MS, masu salmon; DV, Dolly Varden; and SL, Siberian stone loach.

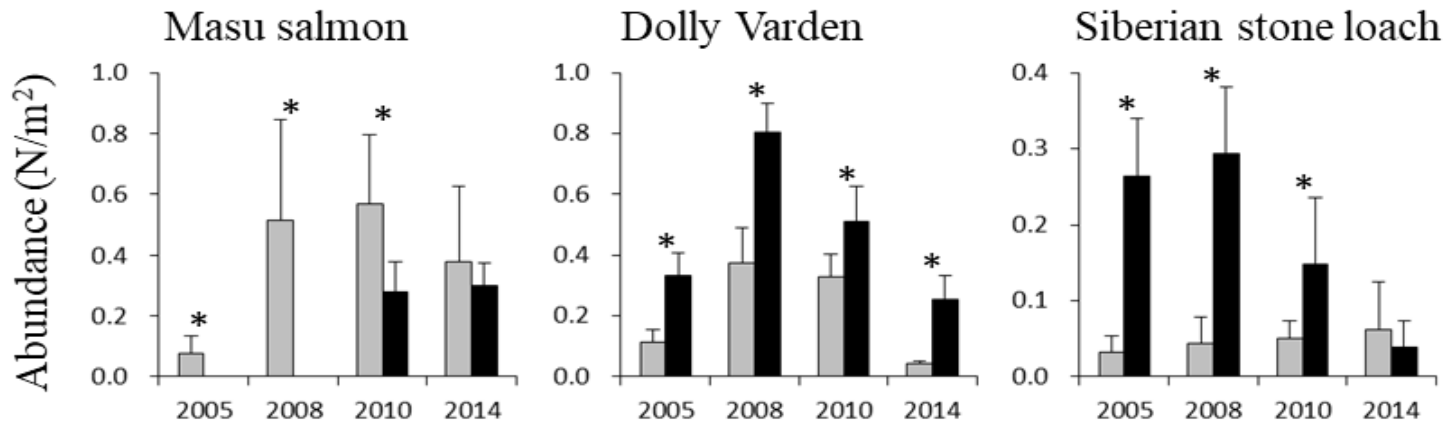

Figure 8. Temporal changes in the fish abundance $\left(\mathrm{N} / \mathrm{m}^{2}\right)$ in the downstream (gray bar) and upstream (black bar) reaches of the dam pre- (2005 and 2008) and post-dam-removal (2010 and 2014). Asterisks above the bars indicate significant differences between the downstream and upstream reaches ${ }^{*} p<$ $0.05)$. 
Table 1. Physical environments (mean \pm standard deviation) in the downstream (down) and upstream (up) reaches of the dam in the Ikeshomanai Stream before (2005 and 2008) and after (2010 and 2014) dam removal.

\begin{tabular}{|c|c|c|c|c|c|c|c|c|c|c|}
\hline Reach & Year & Channel width (m) & Depth (cm) & Current Velocity $(\mathrm{cm} / \mathrm{s})$ & Bedrock (\%) & Sand (\%) & Gravel (\%) & Pebble (\%) & Cobble (\%) & Boulder (\%) \\
\hline \multirow[t]{4}{*}{ Downstream } & 2005 & $8.1 \pm 0.9$ & $19.2 \pm 3.0$ & $47.7 \pm 7.3$ & $37.0 \pm 20.7$ & $1.0 \pm 1.7$ & $3.7 \pm 2.3$ & $33.0 \pm 21.6$ & $21.7 \pm 17.9$ & $3.7 \pm 4.5$ \\
\hline & 2008 & $7.2 \pm 1.4$ & $22.1 \pm 1.9$ & $50.6 \pm 9.5$ & $45.8 \pm 24.8$ & $0.5 \pm 0.8$ & $0.8 \pm 0.8$ & $16.2 \pm 9.5$ & $31.0 \pm 17.7$ & $5.7 \pm 5.0$ \\
\hline & 2010 & $5.3 \pm 0.8$ & $21.1 \pm 0.9$ & $52.7 \pm 6.1$ & $17.3 \pm 18.0$ & $0.2 \pm 0.4$ & $0.5 \pm 0.8$ & $20.0 \pm 13.4$ & $59.5 \pm 11.6$ & $2.5 \pm 3.5$ \\
\hline & 2014 & $6.6 \pm 1.5$ & $26.4 \pm 6.2$ & $58.4 \pm 6.6$ & $18.7 \pm 29.5$ & $1.0 \pm 0.9$ & $8.0 \pm 11.2$ & $20.7 \pm 18.7$ & $44.7 \pm 24.7$ & $7.0 \pm 4.3$ \\
\hline \multirow[t]{4}{*}{ Upstream } & 2005 & $6.4 \pm 0.7$ & $19.6 \pm 1.5$ & $38.7 \pm 5.4$ & $6.7 \pm 7.4$ & $1.0 \pm 1.1$ & $5.3 \pm 4.1$ & $40.0 \pm 21.1$ & $41.7 \pm 19.4$ & $5.3 \pm 7.8$ \\
\hline & 2008 & $6.0 \pm 0.7$ & $23.1 \pm 2.2$ & $46.9 \pm 9.7$ & $7.2 \pm 5.7$ & $0.7 \pm 0.8$ & $2.5 \pm 1.4$ & $15.0 \pm 5.6$ & $58.8 \pm 8.2$ & $15.8 \pm 6.7$ \\
\hline & 2010 & $4.7 \pm 0.5$ & $22.5 \pm 5.0$ & $38.6 \pm 3.1$ & $4.5 \pm 4.5$ & $0.8 \pm 1.0$ & $2.2 \pm 1.7$ & $9.3 \pm 5.4$ & $65.8 \pm 11.9$ & $17.3 \pm 8.3$ \\
\hline & 2014 & $5.5 \pm 0.9$ & $26.6 \pm 4.2$ & $52.4 \pm 4.5$ & $9.5 \pm 8.3$ & $1.2 \pm 1.8$ & $0.8 \pm 0.8$ & $10.2 \pm 2.6$ & $56.8 \pm 12.5$ & $21.5 \pm 9.8$ \\
\hline
\end{tabular}




\subsection{Spatiotemporal Changes in Distribution of Masu Salmon Redds}

The distribution of masu salmon redds in the Ikeshomanai Stream was limited by the dam in 2008 before dam removal, and the number of redds was similar to that in the Toubatsu Stream (Figure 9). In 2010, after the dam removal, the redd distribution extended upstream beyond the dam. Although the number of redds in D1 decreased after the dam removal, several redds were formed in the newly accessible upstream section of the dam.

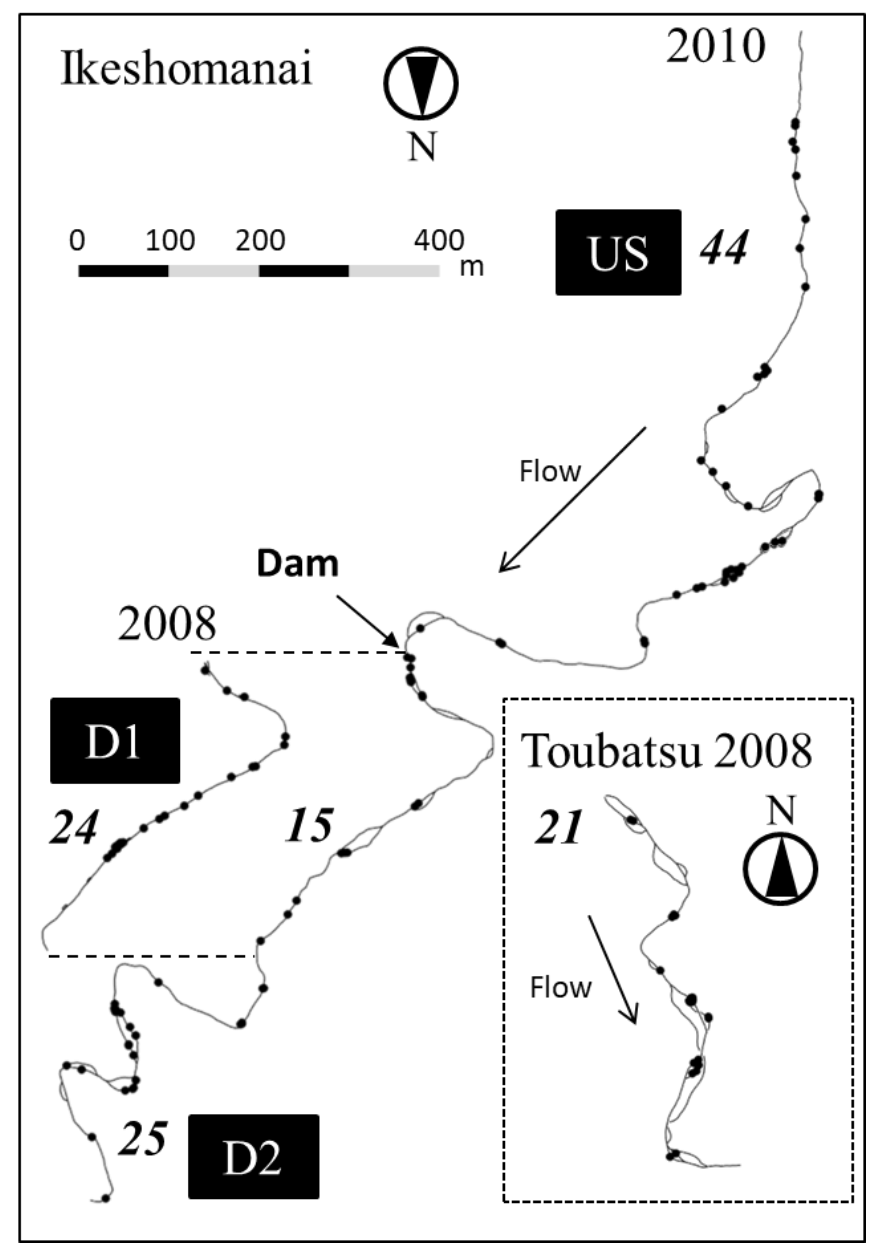

Figure 9. Spatiotemporal changes in the distribution of the redds of masu salmon in the Ikeshomanai Stream before (2008) and after (2010) dam removal (February 2009). The solid circles denote the locations of the redds. US, D1, and D2 indicate the sections of upstream, immediate downstream, and further downstream of the dam, respectively. The redd distribution in the Toubatsu Stream, 2008, is also shown. The italic numeric characters denote the number of the redds in each study section in each year.

\section{Discussion}

\subsection{Channel Unit as a Fish Habitat}

Salmonids showed strong preference to the side channels and pools in all three seasons, indicating that these habitats are essential for their life histories and function as the growing and winter habitats in our study streams. The rapids also functioned as a habitat for Dolly Varden during any season. Dolly Varden, which is mostly a stream-resident type in our study region, become larger than the stream-dwelling masu salmon at age 0 and age 1 . In addition, Dolly Varden have a higher adaptability to cold water than masu salmon [33]. Therefore, Dolly Varden could dominantly use the rapids, even though they have fast and turbulent flows. Siberian stone loach preferred the side channels, 
rapids and pools, and shifted their habitats seasonally. Overall, in our study streams, a set of side channels, pools, and rapids were identified as critical for satisfying the seasonal habitat requirements of the fish assemblages and maintaining the fish populations.

\subsection{Effects of Dam Removal on Channel-Unit (Fish Habitat) Structures}

The partial dam removal temporarily decreased the bedrock outcrop and recovered habitat structures (repeated sequence structures including side channels, pools, and rapids) critical for the fish assemblage in the study streams. However, the habitat structures were subsequently altered closer to the pre-removal state and bedrock outcropping was observed again-occurring more distinctly in the downstream section near the dam (D1). These results indicate that dam removal can be potentially used to recover fish habitats through sediment supply from the dam; however, the sustainability of the effect cannot be promised unless additional sediment supply from the upstream is guaranteed.

Sudden dam removal caused more rapid sediment evacuation from the dam compared with step-by-step removal ("phased dam removal") [34]. In addition, the sediment evacuation was more rapid when a smaller dam was removed [35]. The partial dam removal in our study stream was a sudden removal of a small dam. As shown in the previous studies, rapid and mass sediment evacuation after the dam removal was also observed in this study, likely resulting from the flood due to high precipitation on 23 June 2009, four months after the dam removal. The mass sediment evacuation and subsequent downstream aggradation were observed immediately after the rain on June 23 (our colleagues' observation on 30 June 2009, and an engineer's observation on 8 July 2009).

The first mass sediment supply from the dam reduced the bedrock outcrops in the downstream section of the dam and resulted in the formation of diverse and repeated habitat structures, including channel units (pools, rapids, and side channels) critical for the fish assemblages. Downstream mass sediment accumulation after dam removal extended the active channel width and changed the channel form from single-thread to multithread channels [16-19]. In our study stream, the increase in the side channels in the downstream section likely resulted from the formation process of a multithread channel. The appearance of the repeated habitat structures in the downstream sections indicate the recovery of the habitat formation process in an alluvial channel associated with the deposition and scouring of riverbed sediments. Thus, the sediment evacuation from the dam recovered fish habitats in the downstream section of the dam.

Previous studies on dam removal in low-gradient rivers often observed or predicted the initial downstream habitat deterioration following dam removal [12,19]. In such rivers, dam removal is expected to cause downstream mass sediment deposition with rich mud and sand and, thus, bury and simplify fish habitats, particularly for benthic fish and spawning habitats. In high-gradient small streams, such as our study stream, the initial habitat deterioration following dam removal was limited, possibly because fine sediment does not deposit well even in reservoir areas associated with high stream currents, and/or fine sediment is rapidly transported downstream even if the dam removal releases mass fine sediments [34].

In D1, 5.5 years after the dam removal (1 September 2014), the bedrock proportion increased, and the habitat structures were simplified again. The large amount of sediment supplied to the river channel intermittently moved downstream during each flood and influenced the habitat structures [36-38]. Therefore, the return of habitat structures toward the pre-removal state would be caused by the re-transportation of sediments to lower sections including D2. However, in D2, the side channel increased, likely due to the active channel widening and riverbed aggradation, owing to the re-transportation of sediments from D1. The bedrock also increased in D2, resulting from the subsequent channel incision following the channel widening and aggradation [2,18]. The duration of sediment evacuation after the removal of the smaller dam was relatively shorter [34], although the smaller dam removal caused more rapid sediment evacuation [35]. When the sediment re-transportation exposed the bedrock, transferable sediments in the upstream sections of the dam were already scarce. 
Once bedrock appears in high-gradient mountain streams, it can be difficult to retain sediments transported from upstream reaches due to low riverbed roughness. However, when a large amount of sediment is produced by mass movement, such as landslides and debris flows, the bedrock may be covered by sediments again, and the alluvial channel form may be maintained for a longer term. Partial, but extensive, dam removal ensures sediment movement, which maintains such long-term habitat dynamics. Further long-term monitoring of our study stream and other streams is necessary for the proactive planning of future dam removal projects.

\subsection{Biophysical Responses to Dam Removal}

Similar to the changes in the channel unit structures after dam removal, the physical environments in the downstream reaches (within D1) distinctly changed and became similar to those of the upstream reaches in 2010; however, in 2014, the physical environments returned slightly to the pre-removal state. These results, based on the reach-scale observations, also indicated the downstream re-transportation of sediments, including cobble, and the decrease in transferable sediments in the dam and the upstream sections in 2014.

The dam removal resolved the enforced retention of spawning masu salmon below the dam and extended the accessible area of spawning masu salmon to the original range prior to the dam's construction. Consequently, masu salmon could promptly recolonize the upstream section of the dam, as also reported by previous studies on other anadromous fish [39-42]. The recovery of longitudinal connectivity for anadromous fish could be a strongly promised success in dam removal projects. Thereby, the fish assemblage composition in the upstream section became similar to that in the downstream section after the dam removal. However, the fish assemblage compositions in 2014 were slightly different between the downstream and upstream reaches. The main factor of the difference could be the difference in the Dolly Varden abundance between these reaches. Dolly Varden were distributed in the upper part of mountain streams more than any other salmonid species in Hokkaido [33]. Therefore, the upstream-leaning distribution of Dolly Varden could remain stable even after dam removal.

The gradual decreases in abundance of Dolly Varden and Siberian stone loach in the upstream reach from 2008 to 2014 may be attributed to the continuing indirect effects of dam removal in 2009 . One of the possible indirect effects could be the interspecific competition for food resources following the recolonization of masu salmon. Dolly Varden shifted their foraging behavior from drift to benthos foraging when it was difficult to obtain drifting prey, which was caused by interspecific competition [43]. In addition, Dolly Varden were distributed near the stream bottom and predominantly fed on benthos in the stream with other sympatric salmonids, including masu salmon [44]. Therefore, the recolonization of masu salmon in the upstream reach of the dam may increase the reliance of Dolly Varden on benthos. Subsequently, Dolly Varden may compete against Siberian stone loach, which exclusively fed on benthos before the recolonization of masu salmon, and thus, the abundance of both species might decrease. Another possible effect could be the loss of refuge habitats. Prior to dam removal, the dam was filled with sediment, and thus the low-gradient section stretched more than $300 \mathrm{~m}$ above the dam. The low-gradient section could have relatively moderate currents even during floods and might function as refuge habitats for both species. The low-gradient section disappeared with sediment erosion following the dam removal (change in riverbed gradient, c. $0.6 \%$ to $3.0 \%$ ), and thus the abundance of both species might decrease. In addition, changes in the benthos (prey) abundance after dam removal might also affect the fish abundances. Future studies on these possible effects would be useful for predicting the responses of fish assemblages to dam removal.

The recovery of the distribution range of anadromous fish and the decrease in the abundance of other fish may indicate a return to the fish assemblage structure from prior to the dam's construction. The dam removal led to an unexpected ecological trade-off in a stream ecosystem that had adjusted to new conditions following the dam construction [45]. This suggests the need to be careful in implementing dam removal, otherwise, dam removal may have undesired consequences for stream 
ecosystems. The downstream and upstream reaches of the dam begin to geomorphologically adjust toward a new dynamic equilibrium condition after dam removal, and the biological responses also change in the adjustment process $[14,34]$. The present study successfully captured the long-term effects of dam removal on the biophysical conditions; however, the sampling frequency and data from the reference sites were limited. Further studies are needed to understand the comprehensive ecological effect of dam removals.

Author Contributions: Conceptualization, S.N., T.S., Y.K., D.N., and F.N.; methodology, all; software, S.N.; validation, all; formal analysis, S.N.; investigation, all; data curation, S.N., N.I., T.S., and H.K.; writing-original draft preparation, S.N., N.I., and T.S.; writing-review and editing, all; visualization, S.N.; supervision, S.N.; project administration, S.N. and F.N.; funding acquisition, S.N. and F.N. All authors have read and agreed to the published version of the manuscript.

Funding: This research was funded by the River Fund of the River Foundation, Japan, the "River Ecology Research Group of Japan" on Shibetsu River from the Ministry of Land, Infrastructure, Transport and Tourism, Japan and the Grants in Aid for Scientific Research (Nos. 18H03407, 26740048) from the Ministry of Education, Culture, Sports, Science and Technology, Japan.

Acknowledgments: The authors extend special thanks to M. Ichimura at the Shibetsu Salmon Museum and S. Arakawa for their great assistance in conducting the redd distribution survey and to $\mathrm{H}$. Iwase at the Hokkaido Gijutsu Consultant, Co., Ltd. for the technical advice on dam removal. We also appreciate the support of $H$. Suzuki and the local government of the town of Shibetsu.

Conflicts of Interest: The authors declare no conflict of interest.

\section{Appendix A}
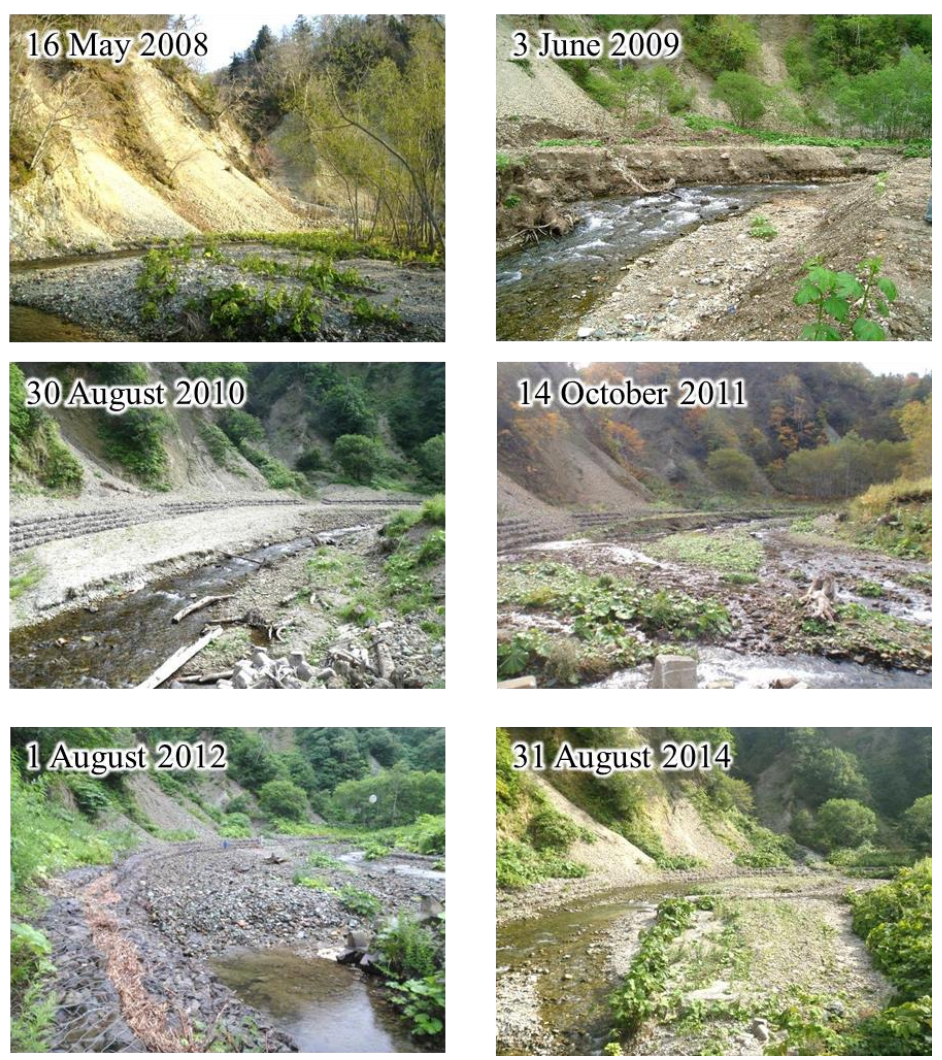

Figure A1. Upstream view from the check dam before (16 May 2008) and after (3 June 2009 -31 August 2014) dam removal (February 2009). Before the removal, the check dam was filled with sediment. After the removal, the impounded sediment was eroded: initially, a narrow channel incised the impounded sediments, and then channel widening proceeded. 


\section{Appendix B}
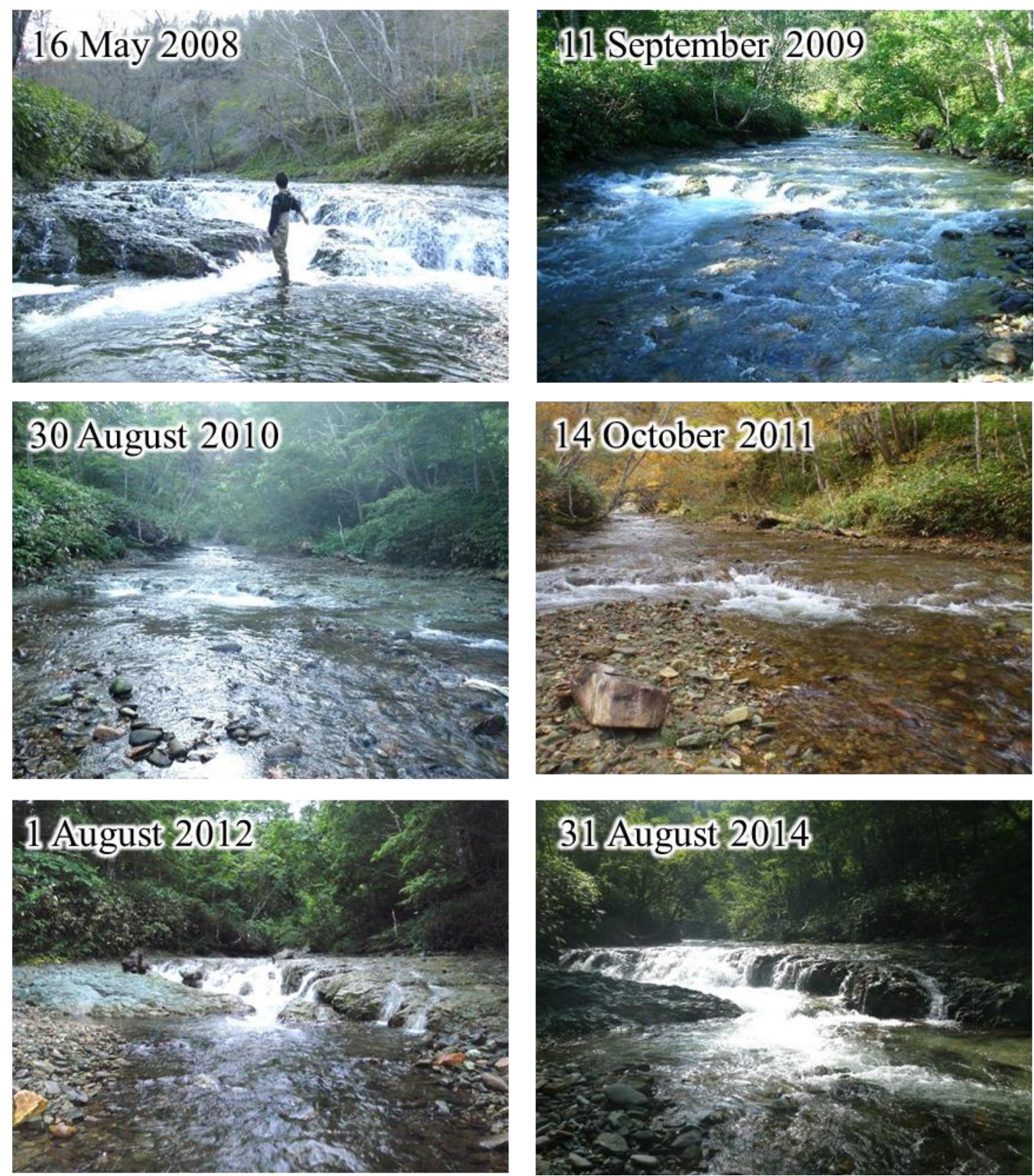

Figure A2. A small step in the downstream section (D1) of the check dam before (16 May 2008) and after (11 September 2009-31 August 2014) dam removal (February 2009). The small step was buried during the first sediment evacuation from the dam and remained to be buried on 14 October 2011. However, on 1 August 2012, the step was exposed to the pre-dam-removal level. This indicates that the sediments buried the step moved downstream during the 10 months between these observations.

\section{References}

1. Sneddon, C.S.; Barraud, R.; Germaine, M.-A. Dam removals and river restoration in international perspective. Water Altern. 2017, 10, 648-654.

2. Foley, M.M.; Bellmore, J.R.; O'Connor, J.E.; Duda, J.J.; East, A.E.; Grant, G.E.; Anderson, C.W.; Bountry, J.A.; Collins, M.J.; Connolly, P.J.; et al. Dam removal: Listening in. Water Resour. Res. 2017, 53. [CrossRef] 
3. Mizoguchi, J.; Kuraji, K. Development of Dam Removal Database in Japan. J. Water Environ. 2006, 19, 43-48. (In Japanese)

4. O'Connor, J.E.; Duda, J.J.; Grant, G.E. 1000 dams down and counting. Science 2015, 348, 496-497. [CrossRef]

5. Foley, M.M.; Magilligan, F.J.; Torgersen, C.E.; Major, J.J.; Anderson, C.W.; Connolly, P.J.; Wieferich, D.; Shafroth, P.B.; Evans, J.E.; Infante, D.; et al. Landscape context and the biophysical response of rivers to dam removal in the United States. PLoS ONE 2017, 12, e0180107. [CrossRef]

6. Kondolf, G.M. Hungry water: Effects of dams and gravel mining on river channels. Environ. Manag. 1997, 21, 533-551. [CrossRef]

7. Poff, N.L.; Hart, D.D. How dams vary and why it matters for the emerging science of dam removal. BioScience 2002, 52, 659-668. [CrossRef]

8. Bellmore, J.R.; Duda, J.J.; Craig, L.S.; Greene, S.L.; Torgersen, C.E.; Collins, M.J.; Vittum, K. Status and trends of dam removal research in the United States. WIREs Water 2016. [CrossRef]

9. Ohtsuki, K.; Iyooka, H.; Nihei, Y.; Yoshimori, Y.; Nakamura, S.; Onikura, N. Sediment erosion and deposition in the former Arase dam reservoir under the dam removal project. J. Jpn. Soc. Civ. Eng. Ser. B1 (Hydraul. Eng.) 2016, 72, I_853-I_858, (In Japanese with English summary).

10. Ohtsuki, K.; Iyooka, H.; Nihei, Y. Sediment release and deposition properties in the Kumagawa River associated with the Arase dam removal project. Adv. River Eng. 2017, 23, 459-464, (In Japanese with English summary).

11. Chung, L.C.; Lin, H.J.; Yo, S.P.; Tzeng, C.S.; Yeh, C.H.; Yang, C.H. Relationship between the Formosan landlocked salmon Oncorhynchus masou formosanus population and the physical substrate of its habitat after partial dam removal from Kaoshan Stream, Taiwan. Zool. Stud. 2008, 47, 25-36.

12. Maloney, K.O.; Dodd, H.R.; Butler, S.E.; Wahl, D.H. Changes in macroinvertebrate and fish assemblages in a medium-sized river following a breach of a low-head dam. Freshw. Biol. 2008, 53, 1055-1068. [CrossRef]

13. Chang, H.Y.; Chiu, M.C.; Chuang, Y.L.; Tzeng, C.S.; Kuo, M.H.; Yeh, C.H.; Wang, H.W.; Wu, S.H.; Kuan, W.H.; Tsai, S.T.; et al. Community responses to dam removal in a subtropical mountainous stream. Aquat. Sci. 2017, 79, 967-983. [CrossRef]

14. Bellmore, J.R.; Pess, G.R.; Duda, J.J.; O'Connor, J.E.; East, A.E.; Foley, M.M.; Wilcox, A.C.; Major, J.J.; Shafroth, P.B.; Morley, S.A.; et al. Conceptualizing ecological responses to dam removal: If you remove it, what's to come? BioScience 2019, 69, 26-39. [CrossRef] [PubMed]

15. Peters, R.J.; Liermann, M.; McHenry, M.L.; Bakke, P.; Pess, G.R. Changes in streambed composition in salmonid spawning habitat of the Elwha River during dam removal. J. Am. Water Resour. Assoc. 2017, 53, 871-885. [CrossRef]

16. Pearson, A.J.; Snyder, N.P.; Collins, M.J. Rates and processes of channel response to dam removal with a sand-filled impoundment. Water Resour. Res. 2011, 47, W08504. [CrossRef]

17. Major, J.J.; O'Connor, J.E.; Podolak, C.J.; Keith, M.K.; Grant, G.E.; Spicer, K.R.; Pittman, S.; Bragg, H.M.; Wallick, J.R.; Tanner, D.Q.; et al. Geomorphic response of the Sandy River, Oregon, to removal of Marmot Dam. US Geol. Surv. Prof. Pap. 2012, 1792, 64.

18. Wilcox, A.C.; O'Connor, J.E.; Major, J.J. Rapid reservoir erosion, hyperconcentrated flow, and downstream deposition triggered by breaching of $38 \mathrm{~m}$ tall Condit Dam, White Salmon River, Washington. J. Geophys. Res. Earth Surf. 2014, 119. [CrossRef]

19. East, A.E.; Pess, G.R.; Bountry, J.A.; Magirl, C.S.; Ritchie, A.C.; Logan, J.B.; Randle, T.J.; Mastin, M.C.; Minear, J.T.; Duda, J.J.; et al. Large-scale dam removal on the Elwha River, Washington, USA: River channel and floodplain geomorphic change. Geomorphology 2015, 228, 765-786. [CrossRef]

20. Ishiyama, N.; Watanabe, K.; Nagayama, S.; Nakamura, F.; Kenmotsu, H.; Takahashi, H.; Maruoka, N.; Iwase, $\mathrm{H}$. The influence of bedrock outcrop on stream fish habitat, and the assessment of restoration in a bedrock stream channel. Ecol. Civ. Eng. 2009, 12, 57-66, (In Japanese with English summary). [CrossRef]

21. Montgomery, D.R.; Buffington, J.M. Channel-reach morphology in mountain drainage basins. Geol. Soc. Am. Bull. 1997, 109, 596-611. [CrossRef]

22. Inoue, S.; Ishigaki, K. Notes on the biology of juvenile masu salmon (Oncorhynchus masou) during winter in the Chihase River, Hokkaido. Jpn. J. Limnol. 1968, 29, 27-36. (In Japanese) [CrossRef] 
23. Collins, M.J.; Snyder, N.P.; Boardman, G.; Banks, W.S.L.; Andrews, M.; Baker, M.E.; Conlon, M.; Gellis, A.; McClain, S.; Miller, A.; et al. Channel response to sediment release: Insights from a paired analysis of dam removal. Earth Surf. Process. Landf. 2017, 42, 1636-1651. [CrossRef]

24. Bisson, P.A.; Montgomery, D.R.; Buffington, J.M. Valley segments, stream reaches, and channel units. In Methods in Stream Ecology, 2nd ed.; Hauer, F.R., Lamberti, G.A., Eds.; Academic Press: San Diego, CA, USA, 2006; pp. 23-49.

25. Nickelson, T.E.; Rodgers, J.D.; Johnson, S.L.; Solazzi, M.F. Seasonal changes in habitat use by juvenile coho salmon (Oncorhynchus kisutch) in Oregon coastal streams. Can. J. Fish. Aquat. Sci. 1992, 49, 783-789. [CrossRef]

26. Nagayama, S.; Kawaguchi, Y.; Nakano, D.; Nakamura, F. Summer microhabitat partitioning by different size classes of masu salmon (Oncorhynchus masou) in habitats formed by installed large wood in a large lowland river. Can. J. Fish. Aquat. Sci. 2009, 66, 42-51. [CrossRef]

27. Kato, F. Life histories of masu and amago salmon (Oncorhynchus masou and Oncorhynchus rhodurus). In Pacific Salmon Life Histories; Groot, C., Margolis, L., Eds.; UBC Press: Vancouver, BC, Canada, 1991; pp. 447-520.

28. Chesson, J. Measuring preference in selective predation. Ecology 1978, 59, 211-215. [CrossRef]

29. Manly, B.F.J.; McDonald, L.L.; Thomas, D.L.; McDonald, T.L.; Erickson, W.P. Resource Selection by Animals: Statistical Design and Analysis for Field Studies, 2nd ed.; Kluwer Academic Publishers: Dordrecht, The Netherlands, 2002.

30. McCune, B. Improving community analysis with the Beals smoothing function. Ecoscience 1994, 1, 82-86. [CrossRef]

31. R Core Team. R: A Language and Environment for Statistical Computing; R Foundation for Statistical Computing: Vienna, Austria, 2019; Available online: https://www.R-project.org/ (accessed on 31 October 2019).

32. Oksanen, J.; Blanchet, F.G.; Friendly, M.; Kindt, R.; Legendre, P.; McGlinn, D.; Minchin, P.R.; O’Hara, R.B.; Simpson, G.L.; Solymos, P.; et al. vegan: Community Ecology Package. R Package Version 2.5-6. 2019. Available online: https://CRAN.R-project.org/package=vegan (accessed on 31 October 2019).

33. Fausch, K.D.; Nakano, S.; Ishigaki, K. Distribution of two congeneric charrs in streams of Hokkaido Island, Japan: Considering multiple factors across scales. Oecologia 1994, 100, 1-12. [CrossRef]

34. Major, J.J.; East, A.E.; O'connor, J.E.; Grant, G.E.; Wilcox, A.C.; Magirl, C.S.; Collins, M.J.; Tullos, D.D. Geomorphic responses to dam removal in the United States-A two-decade perspective. In Gravel-Bed Rivers: Processes and Disasters, 1st ed.; Tsutsumi, D., Laronne, J.B., Eds.; John Wiley \& Sons Ltd.: West Sussex, UK, 2017; pp. 355-383.

35. Stanley, E.H.; Doyle, M.W. Trading off: The ecological effects of dam removal. Front. Ecol. Environ. 2003, 1, 15-22. [CrossRef]

36. Nakamura, F.; Maita, H.; Araya, T. Sediment routing analyses based on chronological changes in hillslope and riverbed morphologies. Earth Surf. Process. Landf. 1995, 120, 333-346. [CrossRef]

37. Kasai, M.; Marutani, T.; Brierley, G. Patterns of sediment slug translation and dispersion following typhoon-induced disturbance, Oyabu Creek, Kyushu, Japan. Earth Surf. Process. Landf. 2004, 29, 59-76. [CrossRef]

38. Miyazaki, T.; Yamada, T.; Marutani, T. Influence of the mobility of the coarse particles on the sediment pulse evolution in torrential rivers. J. Jpn. Soc. Eros. Control Eng. 2008, 61, 5-15, (In Japanese with English summary).

39. Burdick, S.M.; Hightower, J.E. Distribution of spawning activity by anadromous fishes in an Atlantic slope drainage after removal of a low-head dam. Trans. Am. Fish. Soc. 2006, 135, 1290-1300. [CrossRef]

40. Hitt, N.P.; Eyler, S.; Wofford, J.E.B. Dam removal increases American eel abundance in distant headwater streams. Trans. Am. Fish. Soc. 2012, 141, 1171-1179. [CrossRef]

41. Hogg, R.; Coghlan, S.M., Jr.; Zydlewski, J. Anadromous sea lampreys recolonize a Maine coastal river tributary after dam removal. Trans. Am. Fish. Soc. 2013, 142, 1381-1394. [CrossRef]

42. Lasne, E.; Sabatié, M.-R.; Jeannot, N.; Cucherousset, J. The effects of dam removal on river colonization by sea lamprey Petromyzon marinus. River Res. Appl. 2015, 31, 904-911. [CrossRef]

43. Nakano, S.; Fausch, K.D.; Kitano, S. Flexible niche partitioning via a foraging mode shift: A proposed mechanism for coexistence in stream-dwelling charrs. J. Anim. Ecol. 1999, 68, 1079-1092. [CrossRef] 
44. Nakano, S.; Kaeriyama, M. Summer microhabitat use and diet of four sympatric stream-dwelling salmonids in a Kamchatkan stream. Fish. Sci. 1995, 61, 926-930. [CrossRef]

45. Ishiyama, N.; Ryo, M.; Kataoka, T.; Nagayama, S.; Sueyoshi, M.; Terui, A.; Mori, T.; Akasaka, T.; Nakamura, F. Predicting the ecological impacts of large-dam removals on a river network based on habitat-network structure and flow regimes. Conserv. Biol. 2018, 32, 1403-1413. [CrossRef]

Publisher's Note: MDPI stays neutral with regard to jurisdictional claims in published maps and institutional affiliations.

(C) 2020 by the authors. Licensee MDPI, Basel, Switzerland. This article is an open access article distributed under the terms and conditions of the Creative Commons Attribution (CC BY) license (http://creativecommons.org/licenses/by/4.0/). 